\title{
Pengaruh Penggunaan Media Sosial (Instagram) Terhadap Prestasi Akademik Mahasiswa
}

\author{
${ }^{1}$ Joy Maranatha Tarigan, ${ }^{2}$ Tritjahjo Danny Soesilo, ${ }^{3}$ Sapto Irawan \\ ${ }^{1}$ Bimbingan dan Konseling, Universitas Kristen Satya Wacana, \\ ${ }^{2}$ Bimbingan dan Konseling, Universitas Kristen Satya Wacana, \\ ${ }^{3}$ Bimbingan dan Konseling, Universitas Kristen Satya Wacana \\ Correspondence:email. joymtarigan@gmail.com
}

\begin{abstract}
Abstrack: Media sosial telah menjadi salah satu bagian dari masyarakat, Pengguna media sosial yaitu mahasiswa membuat setiap orang saling berkomunikasi dan berbagi informasi. Tujuan penelitian adalah untuk mengetahui pengaruh penggunaan media sosial (instagram) terhadap prestasi akademik. Subyek penelitian adalah mahasiswa BK FKIP UKSW Angkatan 2015. Metode analisis data yang digunakan adalah analisis jalur. Berdasarkan analisis data didapatkan hasil sig $=0,711>0,05$ sehingga dapat dikatakan bahwa tidak terdapat pengaruh yang signifikan. Nilai data $t=0,373<2,002$ dan nilai $R$ Square adalah 0,002 , berdasarkan hasil tersebut, dapat disimpulkan bahwa tidak ada pengaruh yang signifikan antara penggunaan media social (instagram) terhadap prestasi akademik karena pengaruh yang ada sebesar $0,2 \%$ dan 99,8\% dipengaruhi oleh faktor lain yang tidak dijelaskan di dalam penelitian ini.
\end{abstract}

Kata kunci: Penggunaan Media Sosial (Instagram), Prestasi Akademik.

\begin{abstract}
Social media has become one part of the society, social media users, especially students, make everyone communicate with each other and share information. This research aimed to identifying the influence of using social media (instagram) on academic achievement. The subjects of the study were the 2015 SWCU FKIP BK students. The data analysis method used was path analysis. Based on data analysis, the results obtained sig $=0.711>0.05$ so that it can be said that there is no significant effect. Data values $t=0.373<2.002$ and the value of $R$ Square is 0.002 , according the results, the concluded that there is no significant influence between the using of social media (instagram) on academic performance because of the influence of $0.2 \%$ and $99.8 \%$ influenced by other factors not explained in this research.
\end{abstract}

Keyword: Use Social Media (Instagram), Academic Achievment

\section{PENDAHULUAN}

Prestasi akademik merupakan hasil yang dicapai oleh siswa dalam waktu tertentu pada mata pelajaran tertentu yang diwujudkan dalam bentuk angka atau simbol tertentu (Eryanti \& Rika, 2013). Setiawan dikutip Chairiyati (2013) berpendapat bahwa prestasi akademik merupakan tingkat pencapaian keberhasilan terhadap sebuah tujuan, karena suatu usaha belajar yang telah dilakukan secara optimal.
Alex Sobur (2006) menyatakan bahwa prestasi akademik merupakan perubahan dalam hal kecakapan tingkah laku, atau kemampuan yang dapat bertambah selama beberapa waktu dan tidak disebabkan oleh proses pertumbuhan, tetapi karena adanya situasi belajar.

Sekarang telah terjadi banyak perkembangan teknologi informasi, salah satunya adalah telah berkembang juga sebuah media sosial yang membuat para penggunanya termasuk mahasiswa dapat 
berinteraksi dengan orang lain yang tidak satu tempat dengannya. Media sosial atau biasa disingkat medsos telah menjadi bagian dari masyarakat modern. Media sosial merupakan situs yang membuat setiap orang bisa membuat web page pribadi, kemudian berhubungan dengan sesama pengguna media sosial untuk berbagi informasi dan berkomunikasi. Selain untuk berhubungan dengan sesama, ternyata media sosial dapat digunakan untuk keperluan lain. Media sosial dapat digunakan sebagai sarana promosi untuk meningkatkan minat beli konsumen (Indika \& Jovita, 2017). Melalui penelitiannya, Siswanto (2013) menemukan bahwa media sosial dapat digunakan sebagai media untuk meningkatkan hasil penjualan pada usaha kecil dan menengah. Hal ini juga didukung oleh hasil penelitian yang dilakukan oleh Purwidiantoro (2016) yang menemukan bahwa penggunaan media sosial dapat meningkatkan hasil penjualan pada usaha kecil dan menengah. Media sosial juga dapat dijadikan media untuk melakukan kampanye politik karena berfungsi sebagai sarana untuk berkomunikasi dengan para calon pemilih (Anshari, 2013). Hal ini juga didukung oleh Ardha (2014) yang menyatakan bahwa media sosial memainkan peran penting dalam sebuah kampanye politik. Media sosial juga dapat berfungsi sarana yang efektif untuk menyampaikan dakwah (Usman, 2016).

Salah satu situs media sosial yang populer adalah Instagram. Pelaku utama yang meramaikan penggunaan media sosial sebagian besar didominasi oleh usia remaja, khususnya mereka para peserta didik, baik pelajar atau mahasiswa. Banyak yang mempertanyakan kegunaan media sosial tersebut, apakah intensitas yang tinggi dalam menggunakan media sosial benarbenar dapat membantu pelajar dan mahasiswa dalam aktivitas belajar mereka yang dapat mempengaruhi prestasi akademik. Dari pemberitaan media massa ada yang mendukung dikarenakan memang media sosial ini dapat bermanfaat dalam menunjang aktivitas akademik, salah satu manfaat dari media sosial dalam menunjang aktivitas akademik adalah sebagai media pembelajaran (Irwandani \& Juariyah, 2016), Selain itu, media sosial dapat memungkinkan para peserta didik untuk saling berinteraksi dan bertukar informasi dengan peserta didik lainnya melalui berbagai kegiatan seperti diskusi, mengoreksi informasi yang diberikan oleh teman atau kelompok lain tanpa harus berada di tempat dan waktu yang sama (Hanoum, 2014).

Namun, ada pula yang tidak mendukung karena penggunaan media sosial memiliki dampak negatif. Salah satu dampak negatif apabila sering mengakses Facebook yang merupakan media sosial adalah mengganggu kesehatan mata (Wijaya, 2007). Selain itu, media sosial juga dapat disalahgunakan untuk melakukan tindakan Cyberbullyng di kalangan pelajar (Maya, 2015). Pengunaan media sosial yang tidak bertangung jawab juga dapat membuat terjadinya penyebaran informasi yang bersifat tidak benar atau hoax (Rahadi, 2017).

Ada berbagai pengaruh yang dapat ditimbulkan oleh media sosial. Penelitian yang pernah dilakukan di USA (United States of America) yang dilakukan oleh Kirschner dan Karpinski pada tahun 2010 membuktikan bahwa mahasiswa aktif pengguna media sosial cenderung memperoleh nilai GPA (Grade Point Average) yang rendah dibandingkan dengan mahasiswa yang bukan pengguna media sosial.

Andisya Putri Pramudawardani (2016) dalam penelitiannya mendapati bahwa intensitas penggunaan media sosial yang meningkat justru akan membuat prestasi menurun, Kemudian, Hal ini berbeda dengan penelitian yang dilakukan oleh Triyantini (2015), dalam penelitiannya, nilai para siswa yang merupakan pengguna aktif media sosial justru memiliki hasil yang baik dan mereka dapat meningkatkan hasil prestasi belajarnya pada mata pelajaran agama islam. Begitu juga hasil penelitian yang dilakukan oleh Manis Lestari (2016), yang menemukan bahwa mahasiswa yang aktif dalam menggunakan media sosial Facebook juga memperoleh hasil prestasi belajar yang memuaskan. Hal ini juga didukung oleh hasil penelitian yang dilakukan oleh Ramdhani (2016) yang menemukan bahwa penggunaan media sosial memiliki pengaruh yang positif terhadap prestasi belajar walau pengaruhnya relatif kecil. Dari hasil penelitian tersebut dapat diketahui bahwa penggunaan media sosial dapat menimbulkan pengaruh yang berbeda-beda terhadap para penggunanya, Oleh karena itu peneliti melalui penelitian ini mencari tahu apakah terdapat pengaruh penggunaan media sosial terhadap prestasi akademik mahasiswa.

Pada penelitian ini dipilihnya mahasiswa Bimbingan dan Konseling (BK) 2015 sebagai 
subjek penelitian karena data yang diambil melalui angket didapatkan hasil bahwa mahasiswa BK 2015 menghabiskan waktu yang lebih banyak dalam mengakses media sosial dan instagram adalah media sosial yang paling banyak diakses. Kecanduan atau ketergantungan media sosial yang terjadi pada mahasiswa yang telah diketahui adalah adanya penggunaan media sosial saat kelas sedang berlangsung, merasakan kesepian apabila tidak membuka media sosial, merasa menjadi individu yang aneh apabila tidak membuka media sosial, menggunakan media sosial saat sedang berkumpul dengan teman-temannya, kemudian sering menggunakan media sosial saat sedang berbicara dengan kerabat atau teman yang lain. Kecanduan tersebut dapat membuat lulusan BK menjadi tidak fokus saat memberikan layanan bimbingan baik secara klasikal atau berkelompok, kesulitan membangun relasi dengan klien atau peserta didik, terhambat dalam menganalisa data permasalahan siswa, terhambat dalam menganalisis layanan yang dibutuhkan oleh peserta didik, terhambat dalam perencanaan program layanan BK, dan kesulitan dalam membentuk tim kerja yang sinergis dalam pelaksanaan layanan dan bimbingan konseling. Berdasarkan observasi dan wawancara yang dilakukan pada 60 mahasiswa Bimbingan Konseling (BK) FKIP UKSW angkatan 2015, ditemukan bahwa kurang lebih sekitar 50\% diantaranya adalah pengguna aktif media sosial Instagram. Tujuan dari penelitian ini adalah untuk mengetahui pengaruh media sosial terhadap prestasi akademik mahasiswa Progdi BK FKIP UKSW angkatan 2015.

Media sosial merupakan media yang digunakan oleh individu agar menjadi sosial, atau menjadi sosial di dalam jaringan (Daring) dengan cara berbagi isi, berita, foto dan hal lainnya dengan orang banyak (Varinder Taprial dan Priya Kanwar, 2012). B.K Lewis mendefinisikan media sosial sebagai label bagi teknologi digital yang membuat orang untuk berhubungan, berinteraksi, memproduksi dan saling berbagi pesan.

Para ahli memiliki berbagai macam pendapat mengenai media sosial. Chris Garrett (2007) berpendapat bahwa media sosial adalah sebuah alat serta jasa komunikasi yang dapat memfasilitasi hubungan orang banyak yang memiliki kepentingan yang sama. Marjorie Clayman (2011) berpendapat bahwa media sosial merupakan alat pemasaran baru yang memungkinkan penggunanya untuk mengetahui pelanggan dan calon pelanggan dengan cara yang sebelumnya tidak mungkin.

Menurut Budiargo (dalam Dyah, 2016) Instagram adalah media untuk berbagi foto dan video dengan mudah. Melalui situs resminya menyatakan bahwa Instagram adalah sebuah media sosial yang diluncurkan pada tahun 2010 . Kata "insta" pada nama instagram berasal dari kata instan dan kata "gram" berasal dari kata telegram. Tokoh yang mendirikan Instagram adalah Kevin Systrom dan Mike Krieger. Di tahun 2010 Facebook mengakusisi Instagram dengan biaya US\$ 1 Miliar.

Menurut Kamus Besar Bahasa Indonesia, prestasi diartikan sebagai hasil usaha yang dicapai dari apa yang dikerjakan atau yang diusahakan. Seseorang dianggap berprestasi, jika dia telah meraih sesuatu hasil dari apa yang diusahakannya, baik karena hasil belajar, bekerja, atau berlatih keterampilan dalam bidang tertentu. Baiti (2010) menyatakan bahwa prestasi merupakan hasil yang telah dicapai, dilakukan dan dikerjakan oleh seseorang. Sawiji (2008) membagi prestasi menjadi dua yaitu prestasi akademik dan prestasi non akademik. Prestasi akademik menurut Bloom merupakan hasil perubahan perilaku yang meliputi ranah kognitif, ranah afektif dan psikomotor yang merupakan ukuran sebuah keberhasilan (Sugiyanto, 2007). Prestasi akademik merupakan pengetahuan yang telah dicapai pada sebuah mata pelajaran tertentu (Suryabrata, 2010).

Kemudian yang dimaksud dengan akademik adalah keadaan orang-orang yang mampu menyampaikan dan menerima gagasan, pemikiran, ilmu pengetahuan, dan dapat mengujinya secara jujur, terbuka dan leluasa (Fadjar, 2002). Kata akademik berasal dari bahasa Yunani yakni academos yang berarti sebuah taman umum (plasa) yang terletak di sebuah barat laut kota Athena. Selanjutnya kata Academos berubah menjadi akademik, yaitu semacam tempat perguruan. Para peserta perguruan tersebut disebut sebagai academist, sedangkan perguruan tersebut disebut academia.

Alex Sobur (2006) berpendapat bahwa prestasi akademik adalah bentuk perubahan dalam kecakapan tingkah laku, ataupun kemampuan bertambah selama beberapa waktu dan tidak disebabkan proses pertumbuhan, tetapi adanya prestasi belajar. Hasan Abdul Qogar (2000) menyatakan bahwa prestasi akademik adalah hasil dari apa yang telah dikerjakan, 
diciptakan, baik secara individu maupun kelompok.

Prestasi akademik yang dimaksud dalam penelitian ini adalah prestasi mahasiswa dalam perolehan Indeks Prestasi Kumulatif (IPK). Dari hal tersebut dapat disimpulkan bahwa prestasi akademik adalah sebuah kemampuan yang dihasilkan berdasarkan apa yang telah dikerjakan secara individu atau berkelompok dan dipengaruhi oleh usaha belajar.

\section{METODE}

Penelitian ini menggunakan metode penelitian kuantitatif. Penelitian kuantitatif adalah metode penelitian yang sistematis terhadap bagian-bagian dan fenomena serta hubungan-hubungannya.

Populasi dalam penelitian ini adalah mahasiswa angkatan 2015 dari program studi Bimbingan dan Konseling (BK) Universitas Kristen Satya Wacana (UKSW) yang berjunlah 60 orang. Teknik pengambilan sampel penelitian yang digunakan adalah total sampling dikarenakan populasi yang akan diteliti memiliki jumlah kurang dari 100.

Pengumpulan data yang digunakan untuk mencari data adalah dengan menggunakan angket yang disebarkan kepada mahasiswa aktif BK FKIP UKSW Angkatan 2015 di lingkungan kampus UKSW. Instrumen yang disebarkan untuk melihat skala penggunaan media sosial (Instagram), instrumen tersebut memiliki empat pilihan jawaban yaitu Sangat Setuju (SS), Setuju (S), Tidak Setuju(TS) dan Sangat Tidak Setuju (STS). Untuk item favorable ditetapkan skor 4 (SS), 3 (S), 2(TS) dan 1 (STS). Sedangkan untuk item Unfavorable peneliti menetapkan skor 1 (SS), 2 (S), 3 (TS) dan 4 (STS). Kemudian untuk data prestasi akademik yang berupa Indeks Prestasi Kumulatif (IPK) dilambil dari data yang dimiliki oleh fakultas.

Teknik analisis yang digunakan pada penelitian ini adalah teknik analisis jalur. Jonathan Sarwono (2011) menyatakan bahwa analisis jalur (path analisis) merupakan pengembangan dari analisis analisis regresi, sehingga analisis regresi dapat dikatakan sebagai bentuk khusus dari analisis jalur (regresion is sepesicial case of path analysis). Analisis jalur digunakan untuk melukiskan dan menguji model hubungan antar variabel yang berbentuk sebab akibat (bukan bentuk hubungan interaktif / reciprocal).

\section{HASIL DAN PEMBAHASAN}

Dalam penelitian ini dilakukan uji normalitas dan uji Kruskal-Wallis terhadap variabel penggunaan media sosial. Uji normalitas Kolmogorov-Smirnov mrenunjukkan hasil Asymp. Sig. (2-failed) $0.200>0.050$ yang artinya data skor penggunaan media sosial berdistribusi normal. Kemudian untuk uji Kruskal-Wallis dengan hasil signifikansi sebesar 0,533 > 0,05. Lalu untuk data prestasi akademik menggunakan data yang didapatkan dari Biro Administarsi Akademik (BAA) UKSW menunjukkan hasil perolehan IPK mahasiswa BK FKIP UKSW angkatan 2015 dengan Rata-rata (mean) IPK yang diperolehadalah 3,3638 dengan IPK terendah yaitu 1,98 dan IPK tertinggi yaitu 3,95.

Kemudian untuk analisis data dengan teknik analisis jalur pengaruh dari penggunaan media sosial (instagram) terhadap prestasi akademik diperoleh dengan berikut : 
Tabel 1.1 Hasil Analisis Jalur

\begin{tabular}{cccllc}
\multicolumn{2}{l}{ Model Summary } & & & \\
Mo & & & & Std. Error of \\
& & R & R Square & Adjusted R Square & the Estimate \\
\hline 1 & $49^{\text {a }}$ & .0 & .002 & -.015 & 14.475 \\
\hline
\end{tabular}

\begin{tabular}{|c|c|c|c|c|c|}
\hline \multirow[b]{2}{*}{ Model } & \multicolumn{2}{|l|}{ Sum } & \multicolumn{2}{|c|}{ Mean } & \multirow[b]{2}{*}{ Sig. } \\
\hline & Squares & $\mathrm{f}$ & Square & & \\
\hline 1 Regression & 29.078 & & & & $.711^{\mathrm{b}}$ \\
\hline & & & 8 & 139 & \\
\hline Residual & 12151.772 & & & & \\
\hline Total & 12180.850 & 8 & 13 & & \\
\hline
\end{tabular}

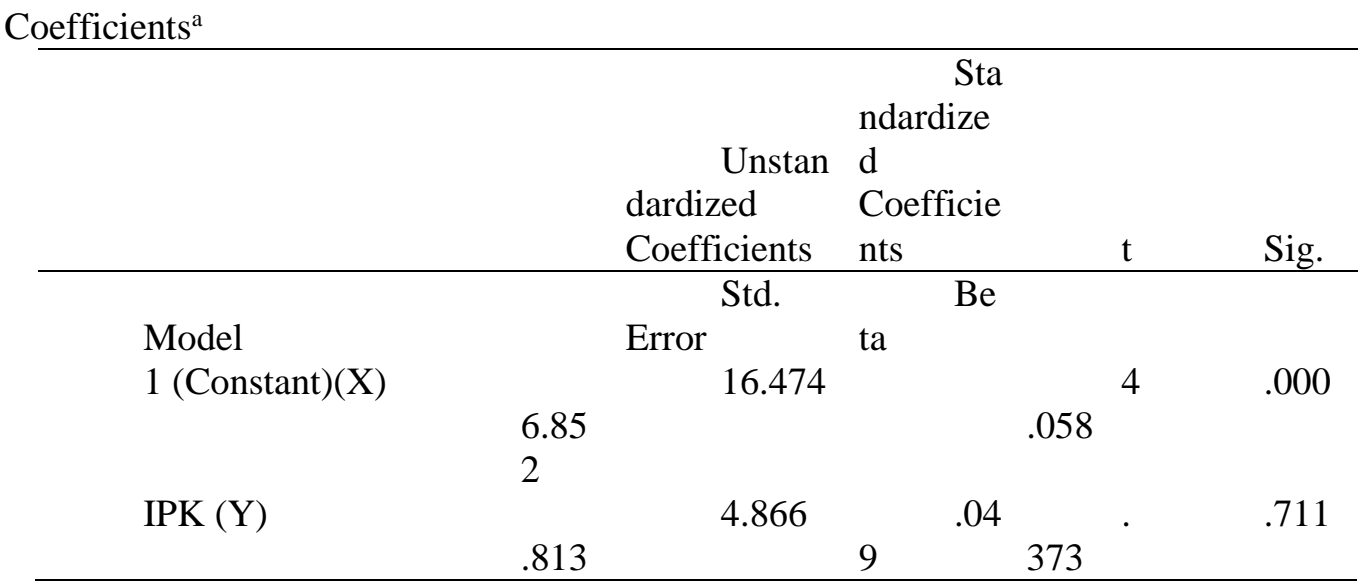

Berdasarkan data model summary pada tabel 1.1 dapat diketahui bahwa nilai dari $R$ Square sebesar 0,002 yang berarti $0,2 \%$. dari hasil tersebut dapat disimpulkan bahwa pengaruh penggunaan media sosial terhadap prestasi akademik hanya memiliki pengaruh sebesar 0,2\%. Kemudian dari data Anova pada tabel 1.1 dapat diketahui dari hasil nilai $\mathrm{F}$ hitung $=0,139$ dengan probabilitas signifikansi 0,711 , dengan derajat kebebasan (dk) penyebut (n-m-1) $=58$. Nilai $\mathrm{F}$ tabel dapat diperoleh hasil 1,58. dengan demikian, nilai $\mathrm{F}$ hitung lebih kecil dari nilai $F$ tabel $(0,139<1,58)$ maka dapat disimpulkan bahwa tidak ada pengaruh yang signifikan. Sedangkan untuk tingkat probabilitasnya 0,711 sehingga lebih besar dari 0,05 , dengan demikian dapat disimpulkan bahwa tidak terdapat pengaruh yang signifikan antara penggunaan media sosial dan prestasi akademik. Kemudian berdasarkan data coefficient pada tabel 1.1, dapat diketahui bahwa $\mathrm{T}$ Hitung = 0,373 dengan tingkat signifikansi $0,05 \mathrm{dan} d \mathrm{dk}$ (derajat kebebasan) n2 yaitu 60-2=58. dengan menggunakan 2 pihak sehingga nilai $\mathrm{T}$ tabel $=$
2,002, karena nilai $\mathrm{T}$ hitung lebih kecil dari $\mathrm{T}$ tabel $(0,373<2,002)$ maka dinyatakan tidak terdapat pengaruh yang signifikan. Hasil analisis membuktikan bahwa tidak terdapat pengaruh yang signifikan antara penggunaan media sosial dan prestasi akademik. Berdasarkan hasil tersebut maka hipotesis ditolak, artinya tidak terdapat pengaruh yang signifikan antara penggunaan media sosial terhadap prestasi akademik.

Ditinjau dari tujuan penggunaannya, media sosial instagram dapat digunakan sebagai sarana untuk bermain atau sarana untuk belajar, dalam penggunaannya untuk bermain, individu yang bersangkutan didorong oleh minat untuk mengakses media sosial (Gok, 2016). Minat membuat individu mengalami kecanduan dalam mengakses akun media sosial. Sedangkan saat media sosial instagram digunakan sebagai sarana untuk belajar, maka media sosial instagram tersebut akan digunakan untuk mencari informasi yang menunjang pembelajarannya, baik pembelajaran secara umum atau pembelajaan secara khusus yang 
sesuai dengan bidang yang sedang dipelajari karena media sosial memiliki berbagai macam aplikasi yang dapat dimanfaatkan untuk belajar melalui informasi dan isu yang dibagikan pada sebuah media sosial (Tim Humas Kementrian Perdagangan RI, 2014).

Seperti yang telah diketahui, bahwa dalam penelitian ini penggunaan media sosial memberikan kontribusi sebesar $0,2 \%$, terhadap prestasi akademik, sedangkan sisanya yang sebesar 99,8\% dipengaruhi oleh faktor lain. Dalam penggunaan media sosial, Manis Lestari (2016) menemukan bahwa jika seorang mahasiswa menggunakan media sosial dalam waktu yang sebentar maka mahasiswa tersebut memiliki prestasi akademik yang baik dikarenakan penggunaan media sosial yang sebentar membuat mahasiswa lebih banyak memanfaatkan waktu untuk belajar agar dapat memperoleh prestasi akademik yang baik. Sebaliknya, apabila seorang mahasiswa menggunakan media sosial dalam waktu yang lama membuat mahasiswa tersebut tidak memiliki waktu yang banyak untuk belajar, sehingga tidak memperoleh prestasi akademik yang baik. Selain itu, penggunaan media sosial yang berlebihan juga akan membuat seseorang sulit untuk berkonsentrasi, kurangnya waktu untuk beristirahat dan terganggunya jam tidur. Sehingga jika seseorang makin sering menggunakan media sosial, maka akan memperoleh prestasi akademik yang buruk, sebaliknya jika seseorang jarang menggunakan media sosial maka akan memperoleh prestasi akademik yang baik.

Kemudian, berdasarkan hasil penelitian sebelumnya (Ramdhani, 2016) terdapat hasil yang menyatakan bahwa penggunaan media sosial memiliki pengaruh terhadap prestasi akademik. Tetapi ada juga hasil penelitian lain seperti yang dilakukan Sulidar Fitri dan Hartatik (2013) yang menyatakan bahwa penggunaan media sosial tidak mempengaruhi prestasi akademik. Prestasi akademik justru dipengaruhi oleh waktu belajar. Adapun hasil penelitian ini menunjukkan bahwa penggunaan media sosial tidak memberikan pengaruh yang signifikan terhadap prestasi akademik karena hanya memberikan kontribusi sebesar $0,2 \%$ terhadap prestasi akademik mahasiswa progdi BK FKIP UKSW Angkatan 2015, dengan hasil tersebut, maka penelitian ini sejalan dengan hasil penelitian yang dilakukan oleh Sulidar Fitri dan Hartatik dan tidak mendukung hasil penelitian yang dilakukan oleh Ramdhani.

Berkaitan dengan hal tersebut, prestasi akademik yang diperoleh tentunya dapat dilihat dari bentuk perubahan dalam kecakapan tingkah laku, atau kemampuan yang bertambah selama beberapa waktu dan tidak disebabkan faktor pertumbuhan, tetapi adanya prestasi belajar (Sobur, 2006). Senada dengan hal tersebut, Setiawan (dalam Naam, 2009) menyatakan bahwa prestasi akademik merupakan suatu pencapaian tingkat keberhasilan belajar. Prestasi akademik dapat dipengaruhi oleh berbagai macam faktor yaitu pertama motivasi belajar, motivasi belajar merupakan dorongan secara internal ataupun eksternal kepada peserta didik yang sedang mengikuti proses pembelajaran dan peserta didik yang memiliki motivasi belajar yang baik akan memperbesar usahanya untuk mencapai prestasi yang tinggi (Saleh, 2014). Faktor kedua adalah manajemen waktu, seseorang yang memiliki manajemen waktu yang baik dapat memperoleh prestasi akademik yang baik karena dapat mengetahui waktu yang tepat untuk belajar (Juliasari \& Kusmanto, 2016). Faktor ketiga adalah minat belajar, ketika seseorang memiliki minat yang tinggi terhadap suatu materi, maka akan lebih memperhatikan materi yang dipelajari sehingga mendapatkan hasil yang maksimal (Lestari, 2013). Faktor keempat adalah Kecerdasan Intelegensi atau IQ (Intelligence Quotient), pada umumnya seseorang yang memiliki IQ tinggi akan lebih mudah dalam melakukakn aktifitas belajar dan dapat memperoleh hasil atau prestasi akademik yang lebih baik dibandingkan seseorang yang memiliki IQ rendah (Khumaidi \& Tarmudji, 2014).

Secara garis besar dapat diambil kesimpulan bahwa prestasi akademik tidak dipengaruhi oleh penggunaan media sosial. Namun hal tersebut dapat dipengaruhi oleh faktor lain yang tidak dijelaskan di dalam penelitian ini.

\section{SIMPULAN DAN SARAN}

Berdasarkan penelitian yang telah dilakukan terhadap mahasiswa Progdi BK FKIP UKSW angkatan 2015, maka dapat disimpulkan bahwa tidak ada pengaruh yang signifikan antara penggunaan media sosial (instagram) terhadap prestasi akademik mahasiswa Progdi BK FKIP UKSW Angkatan 2015 dengan hasil analisis yaitu $R$ Square sebesar 0,002 yang 
berarti pengaruh penggunaan media sosial terhadap prestasi akademik hanya sebesar $0,2 \%$ sedangkan 99,8\% dipengaruhi oleh faktor lain yang tidak dijelaskan dalam penelitian ini. Kemudian dari data Anova diperoleh hasil F hitung $=0,139$ yang lebih kecil dari pada nila $\mathrm{F}$ tabel $=1,58(0,139<1,58)$ maka dapat disimpulkan bahwa tidak ada pengaruh yang signifikan. Sedangkan berdasarkan tingkat probabilitasnya 0,711 sehingga lebih besar dari 0,05 , dengan demikian dapat disimpulkan bahwa tidak terdapat pengaruh yang signifikan antara penggunaan media sosial dan prestasi akademik.

Berdasarkan temuan-temuan dari penelitian ini, maka dikemukakan saran-saran, yaitu , 1 ) Peneliti selanjutnya diharapkan dapat melakukan pengkajian terhadap variabel lain yang dapat mempengaruhi prestasi akademik. 2 ) Program studi dapat menggunakan media sosial untuk keperluan lain seperti menjadikan media sosial sebagai sarana komunikasi antara mahasiswa dengan pihak program studi dan sebagai media pembelajaran jarak jauh $(e-$ learning) saat dosen berhalangan untuk bertemu tatap muka. 3 ) Setiap mahasiswa dapat menggunakan media sosial dengan bijak, karena media sosial dapat digunakan untuk keperluan lain yang bersifat positif seperti pemanfaatan $e$ learning dalam proses perkuliahan, bisnis dan gerakan kepedulian sosial.

\section{DAFTAR RUJUKAN}

Abbas, M. Rivai, D. (2014). Panduan Optimalisasi Media Sosial untuk kementrian perdagangan RI. Retrieved from

http://www.kemendag.go.id/files/pdf/2015/ 01/15/buku-media-sosial- kementerianperdagangan-id0-1421300830.pdf

Anshari, F. (2013). Komunikasi Politik di Era Media Sosial. Jurnal Komunikasi, 8,(1), 91-101. Retrieved from http://www.academia.edu/download/54918 650/jefri.pdf

Ardha, B. (2014). Social Media Sebagai Media Kampanye Partai Politik 2014 di Indonesia. Jurnal Visi Komunikasi, 13(1), 105-120. Retrieved from https://www.neliti.com/publications/14229 8/social-media-sebagai-media-kampanyepartai-politik-2014-di-indonesia

Chairiyati, L. R. (2013). Hubungan Antara SelfEfficacy Akademik dan Konsep Diri Akademik dengan Prestasi Akademik.
Jurnal Humaniora, 4(2), 1125-1133. https://doi.org/https://doi.org/10.21512/hu maniora.v4i2.3553

Eryanto, H \& Swaramarinda, D. R. (2013). Pengaruh Modal Budaya, Tingkat Pendidikan Orang Tua Dan Tingkat Pendapatan Orang Tua Terhadap Prestasi Akademik Pada Mahasiswa Fakultas Ekonomi Universitas Negeri Jakarta. Jurnal Pendidikan Ekonomi Dan Bisnis (JPEB), 1(1), 39-61. https://doi.org/https://doi.org/10.21009/JP EB.001.1.3

Febri, T. (2015). Pengaruh Media Sosial Terhadap Prestasi Belajar Siswa Pada Pelajaran Pai Kelas XI di SMA Negeri 1 Sukoharjo TP 2014/2015 (Universitas Muhammadiyah Metro.). Retrieved from https://lib.ummetro.ac.id/index.php?p=sho w_detail\&id $=8393 \&$ keywords=

Fitri, S. \& H. (2013). Pengaruh Facebook Terhadap Nilai Akademik Mahasiswa STMIK AMIKOM Yogyakarta. Jurnal Semnas Teknomedia Online, 1(1), 1-6. Retrieved from https://www.ojs.amikom.ac.id/index.php/s emnasteknomedia/article/view/607

Gok, T. (2016). The Effects of Social Networking Sites on Students' Studying and Habits. International Journal of Research in Education and Science (IJRES), 2(1), 85-93.

Hanoum, R. N. (2014). Mengembangkan Keterampilan Berpikir Tingkat Tinggi Mahasiswa Melalui Media Sosial. Jurnal Edutech, 1(3), 400-408. https://doi.org/http://dx.doi.org/10.17509/e dutech.v13i3.3093

Indika, Deru R, \& Joveita, C. (2017). Media Sosial Instagram Sebagai Sarana Promosi Untuk Meningkatkan Minat Beli Konsumen. Jurnal Bisnis Terapan, 1(1), 25-31. Retrieved from http://journal.ubaya.ac.id/index.php/JIBT/a rticle/download/296/192

Irwandani \& Juariyah, S. (2016). Pengembangan Media Pembelajaran Berupa Komik Fisika Berbantuan Sosial Media Instagram Sebagai Alternatif Pembelajaran. Jurnal Ilmiah Pendidikan Fisika Al-BiRuNi, 5(11), 33-42. https://doi.org/https://doi.org/10.24042/jpif albiruni.v5i1.103

Juliasari, Nurita \& Kusmanto, B. (2016). Hubungan Antara Manajemen Waktu 
Belajar, Motivasi Belajar, Dan Fasilitas Belajar Dengan Prestasi Belajar Matematika Siswa SMP Kelas VIIseKecamatan Danurejan Yogyakarta. UNION: Jurnal Pendidikan Matematika, 4(3), 405-411. https://doi.org/http://dx.doi.org/10.30738/. v4i3.435

Khumaidi, K., \& Tarmudji, T. (2014). Pengaruh Kecerdasan Intelektual (IQ), Cara Belajar, dan Kreativitas Guru Dalam Pembelajaran Terhadap Prestasi Belajar Ekonomi Siswa Kelas XI IPS di SMA Negeri 1 Bangsri Kabupaten Jepara. Economic Education Analysis Journal, 3(2), 307-310. Retrieved from

https://journal.unnes.ac.id/sju/index.php/ee aj/article/view/3931

Kirschner, Paul A \& Karpinski, A. . (2010). Facebook ${ }^{\circledR}$ and Academic Performance. Journal Computers in Human Behavior, 26(6), 1237-1245. https://doi.org/doi : https://doi.org/10.1016/j.chb.2010.03.024

Lestari, I. (13AD). Pengaruh Waktu Belajar Dan Minat Belajar Terhadap Hasil Belajar Matematika. FORMATIF : Jurnal Ilmiah Pendidikan MIPA, 3(2), 115-122. https://doi.org/http://dx.doi.org/10.30998/f ormatif.v3i2.118

Lestari, M. (2016). Hubungan Penggunaan Jejaring Sosial Facebook Dengan Prestasi Belajar Mahasiswa Universitas Tribuwana Tunggadewi Malang Program Studi Ilmu Keperawatan Angkatan 2012. Jurnal Ilmiah Mahasiswa Keperawatan. Jurnal Ilmiah Mahasiswa Keperawatan, 1(2), 94100. Retrieved from https://publikasi.unitri.ac.id/index.php/fike s/article/viewFile/427/345

Maya, N. (2015). Fenomena Cyberbullying di Kalangan Pelajar. Jurnal Ilmu Sosial Dan Politik, 4(3), 443-450. Retrieved from https://publikasi.unitri.ac.id/index.php/fisip /article/view/125/160

Pramudawardani, A. P. (2016). Pengaruh Intensitas Penggunaan Jejaring Sosial Facebook dan Twitter Terhadap Prestasi Belajar Mahasiswa Pendidikan IPS (Universitas Negeri Yogyakarta). Retrieved from http://journal.student.uny.ac.id/ojs/index.p $\mathrm{hp} /$ social-

studies/article/download/4121/3781

Purwidiantoro, Hari Moch, Kristanto S.W, Danny Fajar, \& Hadi, W. (2016). Pengaruh Penggunaan Media Sosial Terhadap Pengembangan Usaha Kecil Menengah (UKM). Jurnal Ilmiah Ekacida Dinamika Ekonomika, 1(1), 30-39. Retrieved from http://journal.amikomsolo.ac.id/index.php/ ekacida/article/view/19

Rahadi, D. R. (2017). Perilaku Pengguna Dan Informasi Hoax Di Media Sosial. Jurnal Manajemen \& Kewirausahaan, 5(1), 5869.

https://doi.org/https://doi.org/10.26905/jm dk.v5i1.1342

Ramdhani, M. (2016). Pengaruh Sosial Media (Facebook) Terhadap Prestasi Belajar Mahasiswa Ilmu Komunikasi Universitas Singaperbangsa (UNSIKA) Karawang. Jurnal Politikom Indonesiana, 1(1), 66-78. Retrieved from https://journal.unsika.ac.id/index.php/politi komindonesiana/article/view/325

Saleh, M. (2014). Pengaruh Motivasi, Faktor Keluarga, Lingkungan Kampus dan Aktif Berorganisasi Terhadap Prestasi Akademik. Jurnal Phenomhenon, 4(2), 109-141.

https://doi.org/http://dx.doi.org/10.21580/p hen.2014.4.2.122

Sarwono, J. (2014). Path Analysis dengan SPSS. Jakarta: Elex Media Komputindo.

Siswanto, T. (2013). Optimalisasi Sosial Media Sebagai Media Pemasaran Usaha Kecil Menengah. Jurnal Liquidity, 2(1), 80-86. https://doi.org/https://doi.org/10.32546/lq.v $2 \mathrm{i} 1.134$

Soesilo, T. D. (2018). Penelitian Inferensial dalam Bidang Pendidikan. Salatiga: Satya Wacana University Press.

Usman, F. (2016). Efektivitas Penggunaan Media Online Sebagai Sarana Dakwah. Jurnal Ekonomi Dan Dakwah Islam (AlTsiqoh), 1(1), 1-8. Retrieved from http://ejournal.ikhac.ac.id/index.php/altsiq/article/ download/154/108 